\title{
CRITICAL INQUIRY AS A WAY TO BREAK THE GLASS BETWEEN "NORMAL" PRACTICES IN THE CHILEAN PUBLIC ACADEMIA AND THE CASE OF COLOR LATIN AMERICAN MIGRANT STUDENTS IN OUR CLASSROOMS: A CALL TO HUMANIZE, A CALL TO REFLECT UPON
}

\author{
LA INVESTIGACIÓN CRÍTICA COMO UNA FORMA DE ROMPER EL CRISTAL \\ ENTRE LAS PRACTICAS 'COMUNES' EN LA ACADEMIA PÚBLICA CHILENA Y \\ EL CASO DE LOS ESTUDIANTES MIGRANTES LATINOAMERICANOS \\ DE COLOR EN NUESTRAS SALAS DE CLASES: UN LLAMADO A HUMANIZAR, \\ UN LLAMADO A REFLEXIONAR”
}

\author{
Pamela Zapata Sepúlveda*, María Emilia Tijoux Merino ${ }^{* *} \&$ Michelle Espinoza Lobos ${ }^{* * *}$
}

\begin{abstract}
This essay concerns the critical voices of 3 women researchers that examine and reflect about the Chilean educational system using the case of color Latin American students, in the context and from a current perspective of their public universities in Chile. Public policies in education, integration and segregation, challenges and current problems present or that could ocurr in our classrooms are included in this piece using experimental writing as a critical approach to tell, break silences, and as a way to evoke and provoke audiences. Taking a step towards action against social injustice and conservative nationalism and racism in the academia.

Key words: Chilean higher education, integraty, social justice, color foreign students, experimental writing, critical methodologies.
\end{abstract}

Este ensayo comprende las voces críticas de tres mujeres investigadoras que analizan y reflexionan sobre el actual sistema educa-
cional chileno, usando el caso de los estudiantes de color en la academia. Estas reflexiones giran en torno a las políticas públicas
en materia de educación, la integración y la segregación, los retos y los problemas actuales o que puedan ocurrir en nuestras
salas de clase, los que son abordados utilizando la escritura experimental como una vía de aproximación crítica para decir,
romper silencios, evocar y provocar audiencias. Dando un paso hacia la acción en contra de la injusticia social, el nacionalismo
conservador y el racismo en el mundo académico.

Palabras claves: educación superior chilena, integración, justicia social, estudiantes extranjeros de color, escritura experimental, metodologías críticas.

\begin{abstract}
"The struggle for critical subjectivity is the struggle to occupy a space of hope - a liminal space, an intimation of the antistructure, of what lives in the in - between zone of undecidability - in which one can work toward a praxis of redemption".

-Peter McLaren, 1997
\end{abstract}

\section{Introduction}

Pamela Zapata writes: I live in a controversial place situated for some people as northern Chile, for others as EXTREME northern Chile, for me
JUST the North-Chilean-TERRITORY of the macro Andean central south region. At the moment of these words I am writing from the corridor of my thoughts, dreams, ideals and my personal conflicts against social injustice in my region. Hence, always confronting my current question about WHAT COULD I DO to use Qualitative Inquiry as a way to support the lives of people suffering in my Chilean regional context.

At the same time, what I could do to create new spaces in the academy to promote a critical view in the classroom with my colleagues and students, and how this could be a way to connect our

\footnotetext{
* School of Psychology and Philosophy at University of Tarapacá, Arica, Chile. Correo electrónico: pzapatas@ uta.cl

** Department of Sociology at University of Chile, Santiago, Chile. Correo electrónico: maemiliatijoux@gmail.com

*** Faculty of Human Sciences at Arturo Prat University, Iquique, Chile. Faculty of Education at Monash University, Australia. Correo electrónico: michelle.espinoza@monash.edu
} 
lives and our problems with the academia and the globe. This as a way to encourage our voices and the voices of our students to do critical qualitative research, to create our local knowledge relieving our current social problems, to teach from decolonized frameworks and promoting the connection between our current problems and our lives in an era of neoliberal fundamentalism (e.g. Denzin \& Giardina, 2015). In this, as Tami Spry (2011:39) says "in the conformative of meaning with others" is where I find myself as a performative autoethnographic researcher.

Now, at the moment I am writing these lines, I am in a safe multicultural academic space at the University of Illinois at Urbana-Champaign [UIUC]- USA, physically distant but worried about my role in the academia. Thinking about how our work could be a way to generate democratic and safe academic spaces to think, to create decolonized and democratic knowledge that could be applied to support the social problems of our communities, to break silences as injustice and violence, improving the well being of the people, and promoting critical social agents [our students] that could do real social transformation in our Chilean society in the XXI century.

\section{Writing as a Method of Inquiry}

In the place where I am (my corridor), I live the act of writing as a method of inquiry, as a way of finding out, understanding language as a constitutive force that permits to create a particular view of reality and of the Self (Richardson \& Adams, 2005). And at the same time, I am writing as a way of life (Richardson, 2014).

\section{Pamela's Story}

In the side of the corridor where I am, I am thinking about the walk I took this morning on campus at UIUC, where I am a postdoctoral visiting scholar and a post doc in training in the International Institute of Qualitative Inquiry. In this sunny day of the end of semester on campus (may 14th of 2015), I am immersed in an atmosphere of joy and celebration. I could see how the undergraduate students are celebrating their graduation with their families and friends, and I see how their faces look so happy. I could listen to them talking to each other in a very lively and fun way. Most of them are taking pictures to capture this important moment in their lives. Everyone would do the same. Do you not believe it? All of this takes place in different locations in the historical and beautiful green areas of the Quad Cam at UIUC. This area is the heart of the students' life in the university. It is a big green main quadrangle surrounded by historic and beautiful buildings with different colleges. In the front, just south of the area, an auditorium protruding imposed on others, it is Foellinger Auditorium. Everybody is very happy now in the Quad Cam, I can feel the distress on their faces, and the pride in them and their parents for having completed their studies. Someone's daughters and sons laugh happily because this is "THE DAY". It's time to celebrate. It's time to share with the friends and classmates from their times as undergraduate students at UIUC.

I am just walking around the Quad Cam looking and enjoying that picture, as a narrative collage (e.g. Denzin, 2001). Beautiful summer dresses, fashionable high heels, beautiful haircuts and hairstyles, uncommon in a city where students usually wear comfortable and casual wear with the big word "ILLINOIS" in their shirts and wearing the colors of the university (orange and blue) as if it were a school uniform, since that means not wasting time on what to wear each day.

I observed how a group of 15 white women with high heels and beautiful dresses with different shiny colors were taking pictures in groups. They are organizing themselves over the railing that is in the front of the Quad Cam at UIUC. They are the main characters of the white color women painting at "UIUC Graduation in 2015".

At the same time but in a place further back in this scene, in the upstairs area of the same garden where the stands that target the main entrance of the building begin, I see how another group of around 20 black women enter the scene. They are wearing the same red dress -as if this color had the meaning of empowerment for color 
women, as a color of their identity, as a color that calls for visibility, as a color of resistance...- they are taking pictures of them also. This group of women looks different in relation to the first group. This, like a picture of the contemporary history of race relation in America (e.g. Denzin, 2002), is as a scene of a Hollywood's movie of a ghetto action film cycle (Watkins quoted in Denzin 2002). This group of women is using the stairs as their stage for photography. The space behind the group of white women (the main center place for taking pictures). They are smiling and talking loudly making their presence felt. But they look like graduate students from a different university, or country, or continent... they are at the bottom of the scene.

In the same picture frame a little further back, I could see a small group of other students, maybe from India, who were taking pictures of themselves, and even further in this "intercultural" university scenary, I see a group of Asian people taking pictures with their parents. How about integration, multiculticulturalism, social order and equal opportunities for minority cultural groups of students, black people, or with ethnicity and other different aspects distant to the stereotypes related to the white American students as the "predominant culture in US"?, just like the white young women who posed happily on the railing in front of the auditorium?

While I walk slowly around the quad, I begin to see myself in the eyes of students, and remember the day of my graduation. My feet are filled with color, not black, not Asian, not Indian, and begin to wonder about my hybridization, about my Latin American origins, immigrants from some distant place in arabia, natives of northern Chile... what color dress I would have worn if I had graduated from UIUC? Before my post doc time at UIUC, I did not know. I saw myself as a white Latin American woman, in my regional context in northern Chile. I never asked myself that before when I was a high school student or an undergraduate student. Our education was from and by white people. Today after a process of encouraging my voice and doing performance autoethnography since 2011 (e.g. Zapata-Sepúlveda, 2012), if I were 15 years younger, and this was the day of my graduation I would be wearing the red dress... this is not because of a monolithic race notion behind the black color women, but I feel as a hybrid color woman different to the whiteness culture in the U.S.

After this walk on campus at UIUC I asked myself if the open policies in higher education are effective or not as I could perceive in the practice in UIUC while thinking about this as the real effort to integrate scholars and students from different countries to this university. In this case the question is: Could it generate in them the sense of integration we would expect in the academia of this century?

If we think about the realities of our Chilean universities and their current growth in a world where migration issues are also increasing in Chile, we could think that what happens in worldclass universities could happen in our universities as well in a few more years. Would the picture I started this piece with be a futuristic image of what we can anticipate? Is this picture an example which reflects the multiculturalism in higher education in XXI century Chile?

In the website of UIUC, the Proclamation University says "more than 500 active institutional partnerships representing more than 50 countries. Last year, we had more than 10,000 international students attend Illinois, hailing from more than 110 countries. And, more than 2,000 students study abroad annually". (University of Illinois, Boards and Trusted, 2015). I am sure that this information is the consequence of a real effort done by UIUC in the sense of inclusive academic policies.

If universities such as UIUC had inclusive policies as I can see when I go to the wonderful ARC-GYM with my international Les Mills fitness trainers Amir or Jinging, or in the faces of international students and professors in the streets, etc., are universities also a reflection of what happens outside the classroom?, and in our Chilean case, are universities the production of differences and inequalities as a way of reproduction of social order based on color of the skin, ethnicity, origin, for example?. 


\section{Michelle's Voice}

I am a woman, a mother, a wife, a daughter, a sister, a teacher, a friend, a researcher, a PhD student. My different 'identities' have been formed based on the experiences that I have lived. I was born in Machali, south-central Chile, but six years after the military coup my parents decided to migrate to Iquique, northern Chile. I became a foreigner in my country. People in Iquique have always stressed the fact that the people who came to live in that virtuous city but were not born there are some sort of 'fake' Iquiqueños.

Iquique is located in the north of Chile at about 1.800 kilometres from the capital, Santiago. It is a port and has one of the largest duty-free commercial port centers of South America, traditionally called Zofri. Copper mining is also an important industry in the city. It is a very multicultural city attracting people from different parts of the country as well as various parts of the world mainly due to its low unemployment rates, the good climate, and the commercial and mining opportunities. In fact, it has been regarded as the most cosmopolitan city in the country as about 10 per cent of its population is foreign (Rodrigo \& Lobo, 2009). A significant number of immigrants come from neighboring countries such as Peru, Bolivia, Argentina, Colombia and Brazil, but there are also immigrants from other parts of the world such as Croatia, Italia, Spain, China, Taiwan, Pakistan, India, the US and even Australia. Another important component of the population of the city is the indigenous people who come to the city from the inlands moved mainly by socioeconomic reasons.

I arrived in that city when I was only 2 and half years old. All my memories are set in that scenario. Being the daughter of working-class parents, who even today work at Feria Romero from Monday to Sunday has contributed to the person I am now. I lived my childhood surrounded by merchants. By people selling fruit in fruit stalls; by people selling clothes, cigarettes, the latest creation of the Chinese market; sharing with people who lived their lives on the run, the infamous chaperos who played pepito paga doble for ages on the streets of the area around the Mercado Centenario. I attended the primary school located on the historical grounds of Escuela Santa Maria de Iquique, charged with the memories of painful past times.

I went to the local public university to get my degree. However, life has taught me so much more than university did. As I grow older I have became more critical and through self-reflection I have decided that I want to be an agent of change. Working at my Alma Matter, having the opportunity to share experiences with people from different social, cultural, political backgrounds, has helped me build my own identity. As a Chilean person living in the north part of the country, my skin color may not have been that different from my neighbors or friends. However, I have always felt a sense of responsibility to others in under-represented and marginalized groups. This is one of the primary reasons I became a teacher. As a student, I rarely had the opportunity to interact with teachers or administrators who could serve as role models for me. Sadly, I believe the story has not changed much during the last thirty years.

In the context of my own experiences as a student-teacher, a school teacher, and finally as a teacher educator, I need to gain a better understanding about education in Chile, and critically viewing education, educational policy, culture, and identity in order to make sense of the reality we face. It is urgent to include the new scenario posed by immigrants and to cater for their needs as universities such as Tarapacá University and Arturo Prat University are at the gates of the border to the rest of Latin American. I want to produce understandings and insights, which I could share with my students and colleagues, with the hope of contributing to the improvement of education in my region, as well as in other localities. It is my passion for education and for what I believe education should be like that underpins my motivation to 
conduct research and ultimately which guides my different identies. Although Chile is a country in which quality and equity in education are the declared forces driving the educational system, the policies in regard to the teaching and learning have been inspired by a dominant economic narrative which aims to develop human capital for the knowledge economy by means of investing in the development of skills and education (Facer, 2011), embracing this idea as an opportunity to increase the nation's economic competitiveness (Ball, 2007). With so much emphasis placed on economic outcomes, educational policies seem to have lost the focus on what education should be.

\section{Questions and Answer Confronting the Global Tendency in Higher Education}

In this sense, Peter McLaren said: "in the pluralizing move to become a society of diverse voices, neoliberal democracy has often succumbed to a recolonization of multiculturalism by failing to challenge ideological assumptions surrounding difference that are installed in its current anti-affirmative-action and welfare "reform" initiatives". In this context, people of color are still placed under the threshold of candidacy for inclusion into the universal right to self-determination and interpolated as exiles from U.S. citinzenship" (McLaren, 1997: 8).

Meanwhile Henry Giroux states: "Public and Higher education have always been fraught with notable inequities and anti-democratic tendencies, but it also once functioned as a crucial reminder of the pivotal role it might play in enabling students to take heed of, understand, and address social problems in the interests of pursuing a vibrant democracy to come. Understandably, this sounds anachronistic in an age when education is being privatized and instrumentalized" (Giroux, 2015).

Henry Giroux argues that the democracy has become ever more fraught, more at risk and the universities needs to take the role of border crossers, embrace civic courage, be socially responsible, and display compassion for others. Where democracy, justice, and freedom need to begin with the education, this, as a system that plays a central role in the development of the identities, values, desires, dreams, and commitments in the students that shape obligations in the society looking to the future. In this sense, Giroux raises the idea that education needs to provide the intellectual, moral, and political referents in order to imagine and construct a better way of our future (e.g. Giroux, 2013).

The autor said that as an important critical project, education is not about test scores, or draconian zero tolerance regimes. It is concerned with how the capacities of young people could be expanded to be creative, question authority, and think with care about a world where justice and freedom are as the common good reaffirmed. Hence, when the students leave the university, their choices and actions will have a broader sense of ethical and social responsibilities and by developing in the university the sense of who they are and their relationship with the larger world will be linked to what kind of world they will be making for themselves and their descendants.

In addition to the above, Henry Giroux said: The education administration is frequently defined by a business culture and corporate strategies that reduces it to a private act of consumption. This situation goes against the creation of the thinking, speaking, acting human, being competent in matters of truth, goodness and beauty to perform the private and public life. "In opposition to the instrumental reduction of education to an adjunct of corporate and neoliberal interests which offer no language for relating the self to public life, social responsibility, or the demands of citizenship. Your generation must take on the challenge of developing critical approaches to education that illuminate how knowledge, values, desire, and social relations are always implicated in power and related to the obligations of engaged citizenship" (Giroux, 2015).

Pamela Zapata asks again: But, are we worried about freedom, shaping identities, values, dreams? Is this a romantic and high speech discourse of the left view of white anglo public intelectual scholars? Could this type of discourse be applied to our regional context in northern Chile? We could do that. But first we need to see us, identify us, and then create the way to promote a critical view in our students and us.

Maria Emilia Tijoux according to Giroux's ideas said about our Chilean realities, that the higher education system is seen as a widespread market for various godos, where knowledge becomes "Little" goods you need a differentiating process 
that produces elites. It has been one of the ugliest aspects of globalization (Standing, 2011:68).

In an economic expansion, the university and education in general are looking to maximize their reserves or their talents. We see therefore a close relationship between equity with the school selected and effectiveness of its economic profitability. Clearly they are a vector of emancipation and progress, and a mechanism for promotion and social change. In this functionalist perspective, the fundamentals of socialization and selection are not questioned, nor the conditions of production of the differences that qualify students, placing them in assigned places. Only undergo reforms.

It is interesting to recall the work of the book The reproduction of Bourdieu and Passeron to make more explicit the rational pedagogy as tacitly works in our classrooms. Perhaps, like them, in an effort to investigate the hidden webs of our educational practices we could discover the cultural privileges legitimized from school to university, to show how fake the success of the privileged classes is when they say that it is natural and personal talents. This charismatic ideology assumes that there are no social classes. In a device type "school" well armed that contributes to the reproduction of domination.

Following these ideas, from the preliminary results of the research project Regular Fondecyt No 1130203 under development by Tijoux (20132015), called "Black inmigrants in Chile: daily practices of racialization / sexualization". Based on interviews and other qualitative strategies, Tijoux found stories that have been considered discrimination and inconsiderate against "black" people living in Chile.

Reflecting on Giroux's words, María Emilia argues that in the Chilean context the school is not at all "autonomous" and despite being constantly evaluated, it has a force rooted in the time it gets to assume that society itself as "truth" to the education considered legitimate because it comes from scientific discourse and teaching that enables seamless education to fulfill its function of social reproduction. But social relations can not be reduced to the mooring between animated by intentions or motivations subjectivities, they are also built in conditions and social positions that make them sometimes more real than the same subjects that articulate. Therefore, rather than describing -directly-attitudes, opinions and aspirations of individual students and teachers, present and visible in the educational process, from sociology should seek the objective logic that is behind the education system, to get to know the principle that explains these same attitudes, views and aspirations.

A sociological study of the pedagogical relationship should treat this relationship, objectified in the "pedagogical action" other than as a simple rapport that measures a performance explicable from the same educational production would be. Do not forget that it is in the act of "inculcating knowledge" that this pedagogical act leads to inequality largely academic success of students and at the same time it allows the success of the elite groups in a way that already have secured their future.

Educational systems are ideal places for reproduction of social inequalities. This is because to exercise teaching is objectively symbolic violence, because from a totally arbitrary power, it imposes an arbitrary culture (Bourdieu, 1976). This difficulty increases when education is still perceived as a liberating possibility to poverty, and the school as the only legitimate place where this liberating process takes place. If in every society the dominant group tries to impose those meanings that the school selects and imposes disguised as a delegation of power by the dominant class. How to account for what cloaking?

At the same time, María Emilia said: Domination presupposes correspondence between social structures and cognitive structures, divisions and objective classification schemes. We can see how this correspondence operates in the implicit endorsement of children, youth and their families in order established by the education system. It is there that the work of cognitive subversion would have to operate to produce political subversion that could break the rules and representations that the order engenders molded according to the needs and intentions of the power structure agents.

Domination is achieved in that manager agents apply categories of perception to the objective structures of the social world that extract such structures, when they perceive and feel the world as a world that is clear, which is given in this way and not other and is therefore the world. Symbolic violence and everything tacit banking on effect seems to have dominated the field itself, but it is an invisible structure that organizes the perception of agents. Domination coming from multiple clandestine persuasions given by the order of things (see the fate or resignation) which are registered in the habitus. 
The linguistic competence of higher education linked to the effort (ratings) is re-translated into the school logic that measures the potential of a particular social situation. Pedagogy reveals the role played by the notion of linguistic capital in communicative effectiveness.

Pamela asks: after that, the question is how do we see the dark-skinned foreigners who have come to our country from neighboring countries or from the rest of Latin America?

The educational system is the main beam, the privileged place that ensures the reproduction of domination ${ }^{1}$, it is in there that social inequalities are generally reproduced between ruling classes and dominated classes, through the exercise of an objectively violent teaching -simbolic- because from an arbitrary power, (the teacher) imposes cultural arbitrariness ${ }^{2}$.

Maria Emilia adds: The logic diagram of the system acts on the entire school career, and restructuring according to the different weight of the factors considered in the same cursus. University education is fragmented, subdivided, depending on the jurisdiction and functions of competition in the process of social ascent: high school, college (undergraduate) and graduate (master's, doctoral). To this accumulation of titles that operate as intellectual nobility titles, adding to their cumulative symbolic force of diplomas own strength is added. It is clear that in every society, the dominant group tries to impose meanings "concealing the power relations" that are the basis of its own strength.

The selection made by the school imposes meanings while cloaking its action in a delegation of power that has been given by the ruling class.

\section{The Case of International Color Students in Two Different Moments and Contexts in Chile}

Pamela writes: Last April in Santiago de Chile, María Emilia Tijoux invited me to participate in a seminar founded by her research Regular Project Fondecyt $\mathrm{N}^{\mathrm{o}} 1130203$. The seminar called Racism in Chile: the skin as a mark of immigration was a really good opportunity to break the glass between the academia and the public policies, the academia to -in- the society. This seminar was really exciting, inspirational and a learning experience for me, and I could be and feel in a real multicultural environment in a public university in my country. I had the opportunity to share and talk with Colombian,
Peruvians, Haitians, Dominicans, and Chilean people studing postgraduate programs in the Host University, or members of ONGs working with migrant people in the capital of Chile.

The international students attending the seminar have the recognition of their studies in Chile. This is the next step for our regional universities in northern Chile where opportunities like this are so difficult to reproduce. Most of the graduate students were linked to the ONG called Fasic in my town, dealing with the case of Colombian people living in Arica, and do not have the opportunity to obtain the recognition of their graduate studies as a simple, fast and cheap process. They are asking for a refugee status, they are asking for life (ZapataSepúlveda, 2015).

In Arica, there are not Colombian women as students in our programs, althought there are Colombian women with degrees and postgraduate studies living in Arica. Unfortunately, most of them are working caring for elderly people in their houses, or cleaning private houses.

Fortunately, the border and the national policies in education opened their borders to Peruvian and Bolivian undergraduate students a few years ago. At the same time, I see with concern how the international Peruvian and Bolivian undergraduate students study together and form new groups between them, as an automatic form of international segregated organization, and frequently I ask myself if this is because they know each other from before, or is this because they only have this option to form student networks in our Chilean University.

But coming back to the seminar about racism in Chile, while I was seating in the room with the audience from different nationalities, I was asking myself who I am - in the capital context. How I feel with international Latin American and color students, and how I could feel the multicultural academic spaces in the capital. I feel again as in a futuristic picture of multiculturalism in higher education.

\section{Pamela Comes Back to the First Picture}

While I was looking at the young women taking pictures in "sectioned" (white people) and segregated (black people) spaces at the Quad Cam of the same university, it came to me that this scene could imply that the university separated students by race, gender and income. I believe 
we need to think and reflect on our universities as a reflection of what really happens out there, because things occur that we prefer not to talk about or talk about them in very academic ways with our rules characterized by colonialism, the heritage of dictatorship as our academic rules, and the consequences of that in the role, uses and abuses of the politics and historical powers and the dinamycs of daily life relationships between scholars, students and both. This commonly based on gender, class, etnicity and political interest.

As Mc Laren states: "Students with the privilege as well as issues of oppression" (Kincheloe and Steinberg, 1997). In this sense, the use of performative writing as Storytelling, helps the "teller and listener; performer and audience, share the goal of participating in an experience which reveals their shared same-ness" (Porter quoted in Denzin, 2001:25).

At the same time, positivism and imperialism as a way of knowledge is understood as the predominant knowledge around the world and a regional university would not have to be the exception. In this sense, all kind of ways that started understanding the knowledge as neutral and ideas supported by another author who has previously published similar ideas in scientific journals. This, although we use the quote of that author, preferably white and American or Spanish people that probably have not written their ideas focused on our Latin American contexts.

\section{What Can we do?}

Using the example behind the picture about the particular intercultural moment of the end of semester at UIUC, and some ideas and realities in our Chilean context of higher education, we wish to respond in this piece to how and what is the educational challenge in the era of a global world in the case of a public university in northern Chile. We could promote citizens (our students) in a global world to identify and relieve their voices in a critical view to produce social transformation against injustice starting in front of our noses: the classroom!

Following Henry Giroux who said: Critical education matters because it questions everything and complicates one's relationship to oneself, others, and the larger world. It also functions to "keep historical memory alive, to give witness to the truth of the past so that the politics of today is vibrantly democratic". Education has always been part of a broader political, social, and cultural struggle over knowledge, subjectivities, values, and the future. Today, public and higher education are under a massive assault, because they represent some of the few places left that are capable of teaching young people to be critical, thoughtful, and engaged citizens who can take risks, stretch their imaginations, and, hold power accountable.

In this sense, fear (understood as the consequences of the repression lived from 1973 in the case of Chile), now defines social relations and leads the legitimization of dominant forms. These conditions lead to a number of challenges for the new generation of students. The questions for Giroux now are: How could we promote students with critical capacities to be agents of change? How would you break the mechanisms that want to turn all black men [or indigenous, or poor, or children of migrant people] into criminals? How could we address the widespread anti-intellectualism that enables a culture of thoughtlessness and violence to continue? What limits could we put to the growing atomization and isolation of everyday life and the ludicrous assumption that shopping is the highest expression of citizenship?.

Pamela questions and answers: Are our universities making the difference of the worldwide tendency of the politics of disposability? I [we] think not! (e.g. Zapata-Sepúlveda et al., 2013).

Are our Chilean lecturers and professors worried for the social value in our students? And are we doing anything about that considering this an important thing to work in higher education? I think not.

At the same time, Michelle asks: Are Chilean universities prepared to face the challenge that has been imposed on them? Has the context in which the educational policies are to be enacted been taken into account? Are academics prepared to educate students, including the international students, according to the imperatives imposed by global forces and taken in by the Chilean government? Are schools ready for the immigrants? My hunch is that dealing with this situation is not going to be easy.

Joe L. Kincheloe and Shirley Steinberg said: how do we move beyond critical pedagogy's traditional concern with critique to a new form of critical transformation? Where do we begin 
the process of creating democratic educational spheres? What role might teachers play in this process? (Kincheloe \& Steinberg, 1997). The response includes race, ethnicity, and class as they intersect with pedagogy in our contemporary neoliberalist time.

Pamela Zapata has some other questions: will we continue teaching as we are a homogeneous bad copy of only one race as fake as the white people? Or could we open our eyes to see our international students or student from the hibridity of their selves? Are we working with our new patterns of immigration of poor and Latin American people living in the border where our University of Tarapaca or/and Arturo Prat University are located? Considering that, what is the meaning of multicultural education for the case of Chile as northern Chile?

\section{Final Thoughts}

In an era marked by the long term effect of political violence in Chile (between 1973 and 1990), present through fear, the use and abuse of power, the knowledge that we transmit and that does not speak, we have a huge amount of work to do.

Henry Giroux said: Education -in higher education- needs to prepare people to enter a society that needs to be reimagined. We need to promote to become agents of social change, teach the skills, knowledge and values that allows us to use them to organize political movements, capable of stopping the destruction of the environment, end the inequalities to improve a more democratic and justice society, and build a world focused on love and generosity and living lives of decency and dignity rather than on selfishness and materialism.

Pamela responses: Critical qualitative research is a way to do that. To think, to dream, to live in and behind our lens of humanity, dignity and looking and asking ourselves, who are us, "citizens who can fashionably choose whatever ethnic combinations we desire in order to reassemble our identity"? (McLaren 1997:7), asking ourselves about how "class, race, and gender stratification and objective constraints and historical determinations restrict the choices of some groups" (McLaren, 1997:8), as the case for example, of marginal students in our classroom as Latin American, dark-skinned, of humble origin, andean migrant or children of internal or external migrant people from Andean people.
Then, what can we do in the academia to improve the life of our suffering community? We could consider we are not the exception of the common tendency argued by Trueba (1989) to be teachers ethnocentrist and insensitive toward minorities in our teaching work and our practice to do that with our students.

In this way, we must ask ourselves about our identity, understand this as "more than the ideological trafficking between nationality and ethnicity; it is the overlapping and mutual intereffectivity of discourse that is configured by the social relations of production", or understand that "nationalism, ethnicity, and capitalism circuits of production can be seen as moving into a shared orbit" (McLaren, 1997:8). As Mc Laren said: we need to create "spaces of hope [that] offer encouragement to the forces of justice... spaces - often private - must be made public. We must be expanded from spaces into spheres - from personal, individual spaces and private epistemologies into public spheres of hope and struggle and collective identities" (McLaren 1997:2).

In a region where our history of sovereignty and loyalties could be the cause for our difficulties to recognize our black and Andean heritage (e.g. Díaz \& Ruz, 2009; Galdames et al., 2013). As McLaren argues, it is necesarry to stress the importance of our diversity and inclusion, as do most multiculturalists, focus on the social and political construction of white supremacy as the dispensation of white hegemony. In this sense, and following Mc Laren ideas, the "whiteness" as distortion field needs to be identified as a cultural disposition and ideology that is linked to particular political, social, and historical arrangements (McLaren, 1997:8).

In our case, linked to the notion of soverignity, the identity of Chilean society, the daily life with the use of different kinds of powers determined by marketplace and as the consequences of the effects of the dictatorship period, the neoliberal democracy (McLaren, 1997:8) that confirms the racist stereotypes at the time that prescribed the Euro-American nationalist myths of supremacy. Stereotypes that McLaren calls fine crimmegrants (McLaren, 1997:9), for the case of Bolivian migrants or Colombian people living in northern Chile (e.g. Butrón, Cavieres, Moscoso y Pérez, 2014), that have become the object of xenophobia as cathegories of ilegal aliens as criminal people, not as a category 
of ethnic group (Gomez-Pena quoted in McLaren, 1997:9).

Stereotypes that our Chilean democratical-political system has not touched yet. This, in a country where what is not said, does not exist. As Mc Laren said (1997) critical pedagogy as a pedagogía fronteriza could service as a form of critical postcolonial hybridity distant to the hybridity concept as a monolithic and authentic form of identity. (e.g. McLaren, 1995). "It speaks to the voiceless and the peripheralized, the marginalized and the excluded" ... "it can be created only if we take the struggle over the social division of labor as seriously as we do with the struggle over meaning and representation" (McLaren, 1997:13).

Only focusing our work on and behind our realities as a border zone in northern Chile, we could find our voices, not white, not black, but different color voices relieving our heritage from our families, our story, and our time, looking and assessing our particular place and how in this place (not only Arica, Arica and Tacna, Iquique, the macro region central-south Andean) our daily life experiences take place.

As George and Louise Spindler suggest (Spindler quoted in Trueba et al., 1990), we could use Reflective-Cultural Analysis or create a new methodology to look at us and help us as teacher to evaluate and identify our interactions and conflicts in our classroom spaces. This could allow us to reveal our unconscious biases and cultural ethnocentrism in dealing especially with minority students in our classroom (Trueba et al., 1990). This in our case from the view of a dimension of cultural transmission of the consequences of our battles with neighboor countries, the consequences of the sovereignty imposed by Pinochet's regime against every feature and sign that might mean to be a "non-chilean person" associated with disloyalty and shame.

Only by recognizing ourselves we can start the social transformation from our classroom to our society. Only by doing that, we could teach and learn with our new generation of students about how from the knowledge we could generate, we could move to a real social transformation that in our case, must include integrity as our reality, academic and social freedom to think, to tell, to create, to dream of a better world, our world where we work with liminality, with disimility, with being betwixt and between, with crossing thresholds, with living in the margins (McLaren, 1997). To do that, interpretive autoethnography as a method, using narrative, meaning, voice, experience, reflexivity, presence, and representation, that challenge terms as voice and presence, indigenous persons in colonized classroom spaces that could turn to oral history, myth, and performance narratives to connect with their [our] lives, and their [our] collective histories (Denzin, 2014).

This, with a realistic and human view of the rich cultural aspects behind our macro region central south Andean, our capital city being the last destination of our dreamer migrant people that see the Chilean society as a better place in the world.

\section{Acknowledgments}

The authors would like to thank the Performance Agreement Project at UTA-MINEDUC, and Regular fondecyt $\mathrm{N}^{\circ} 1130203$ "Black inmigrants in Chile: daily practices of racialization / sexualization".

\section{References Cited}

Ball, S.

2007 Education plc: understanding private sector participation in public sector education London; New York Routledge. Bourdieu, P. \& Passeron, J.C.

1964 Les Héritiers: Les étudiants et la culture. [The Inheritors - French Students and their Relation to Culture] Paris: Editions de Minuit.

Butrón, M.; Cavieres, T.; Moscoso, R. \& Pérez, F.

2014 Construccion del inmigrante boliviano, peruano y colombiano en la ciudad fronteriza de Arica a traves de la prensa escrita. [Construction of the Bolivian, Peruvian and Colombian immigrant in the border city of Arica through the press]. (Unpublished [degree] dissertation). University of Tarapacá, Arica - Chile.
Denzin, N.K.

2001 The reflexive interview and a performative social science. Qualitative Research, 1(1), 23-46.

2002 Reading Race. London: SAGE.

2014 Interpretive autoethnography (2nd ed.). Los Angeles, CA: SAGE

Denzin, N.K. \& Giardina, M.D.

2015 Introduction. In N.K. Denzin \& M.D. Giardina (Eds.), Qualitative inquiry and the politics of research (9-25). Walnut Creek, CA: Left Coast Press Inc.

Díaz, A. \& Ruz, R.

2009 Estado, escuela chilena y población andina en la ex Subdelegación de Putre: Acciones y reacciones durante el período post Guerra del Pacífico (1883-1929). [State, chilean 
school and andean population in the ex-Subdelegation of Putre. Actions and reactions during the period post War of the Pacific (1883-1929)]. Polis (Santiago), 8(24), 311-340.

Facer, K.

2011 Taking the 21st century seriously: young people, education and socio-technical futures. Oxford Review of Education, 38(1), 97-113. doi: 10.1080/03054985.2011.577951

Galdames, L.; Ruz, R. \& Meza, M.

2014 Imaginario nacional en revistas de la frontera norte de Chile post guerra del pacífico: ariqueña (Arica, 1923) y Torbellino (Tacna, 1924). [National imaginary in magazines from the north frontier of Chile post war of the pacific: Ariqueña (Arica, 1923) y Torbellino (Tacna, 1924)]. Interciencia, 39(7), 490-494.

Giroux, $\mathrm{H}$.

2013 Neoliberalism's war against teachers in dark times. Cultural Studies <=> Critical Methodologies, 13(6) 458-468.

2015, May 24 Educated Hope and the Promise of Democracy.Tikkun Daily. Retrieved on May 15th, 2015 from http://www.tikkun.org/tikkundaily/2015/05/26/ educated-hope-and-the-promise-of-democracy/

Kincheloe, J.L. \& Steinberg, S.

1997 Series editor's preface. In P. McLaren (Ed.) Revolutionary multiculturalism: Pedagogies of dissent for the new millennium (xiii-xiv). Boulder, CO: Westview Press.

McLaren, P.

1995 Critical Pedagogy and Predatory Culture: Oppositional Politics in a Postmodern Era. London and New York: Routledge.

1997 Revolutionary Multiculturalism: Pedagogies of Dissent for the New Millennium. Boulder, CO: Westview Press.

Richardson, L. \& Adams, E.

2005 Writing: A method of Inquiry. In N.K.Denzin \& Y. S. Lincoln Eds. The Sage Handbook of Qualitative Research. Third Edition. SAGE

Richardson, L.

2014 Three Words Workshop. Workshop presented at the International Congress of Qualitative Inquiry, University of Illinois at Urbana-Champaign.
Rodrigo, G.M. \& Lobo, A.

2009, 25 October Iquique tiene casi el 10\% de su poblacion extranjera y es la ciudad mas cosmopolita del pais [Iquique has almost $10 \%$ of foreign population and is the most cosmopolitan city in the country]. La tercera, p. 1. Retrieved from http:// www.latercera.com/contenido/680_194898_9.shtml

Spri, T.

2011 Body, paper, stage: Writing and performing autoethnography. Walnut Creek, CA: Left Coast Press.

Standing, G.

2011 The precariat: the new dangerous class. London: Bloomsbury Academic.

Trueba, H.T.

1989 Raising Silent Voices:Educating Linguistic Minorities for the 21st Century. New York: Harper and Row.

Trueba, H.T.; Jacobs, L. \& Kirton, E.

1990 Cultural Conflict and Adaptation: The Case of Hmong Children in American Society. London: RoutledgeFalmer

University of Illinois boards and trusted

2015 International. Retrieved on May 15th, 2015 from http:// illinois.edu/international/index.html.

Zapata-Sepúlveda, P.

2012 Breaking my academic silence to start again making sense of why I am here, Moving from the thin to thick. Thinking about trauma and loss. Qualitative Inquiry, 18, 643-650.

Zapata-Sepúlveda, P.; Jiménez-Benítez, V. \& Concha-Astorga, D.

2013 From the struggle for education to the transformation of society: Challenges and hopes in the Chile of the 21st century. Cultural Studies $<=>$ Critical Methodologies, 13(6) 497-503.

Zapata-Sepúlveda, P.

2015 Experiencias de investigación, desafíos y limitaciones en el trabajo con inmigrantes y refugiados en la ciudad fronteriza de Arica [Research experiences, challenges and constraints in working with immigrants and refugees in the border town of Arica]. Paper presented at the Semminary Racism in Chile: The skin as a mark of inmigration, University of Chile, Santiago, Chile.

\section{Notes}

1 From his early work with Jean-Claude Passeron in 1962: Les Heritiers (heirs), Passeron \& Bourdieu (1964) chooses an object of study that was marked by the crisis of students in the western world. On playback, the authors state that the school perfectly fulfills its social function while in operation and playback methods, says independence with the hierarchies of the social body. The more independent appears against the values of the global society, more so their own values. Pedagogical action then, is an instance of legitimacy of the outcome of the balance of power within the social body.

2 This system has great explanatory power because it is an analytical model that serves as a guideline for analyzing social logics. From the beginning all societies that man has built rests on competition and domination mechanisms that play through generations. There is no society without hierarchies, without power, without domination between the sexes, ages and classes. 
